\section{REFLEKSI HUKUM}

Jurnal Ilmu Hukum
p-ISSN 2541-4984 | e-ISSN 2541-5417

Volume 6 Nomor 1, Oktober 2021, Halaman 87-106

DOI: https:// doi.org/10.24246/jrh.2021.v6.i1.p87-106

Open access at: http:// ejournal.uksw.edu/refleksihukum

Penerbit: Fakultas Hukum Universitas Kristen Satya Wacana

\title{
EKSISTENSI ADAT DALAM KETERATURAN SOSIAL ETNIS DAYAK DI KAMPUNG BONSOR BINUA SAKANIS DAE
}

\author{
Efriani \\ Program Studi Antropologi Sosial, Universitas Tanjungpura|efriani@fisip.untan.ac.id \\ Jagad Aditya Dewantara \\ Program Studi Pendidikan Pancasila dan Kewarganegaraan, Universitas Tanjungpura| \\ jagad02@fkip.untan.ac.id \\ Meliya Fransiska \\ Program Studi Antropologi Sosial, Universitas Tanjungpura|meliyafransiska99@student.untan.ac.id \\ Iwan Ramadhan \\ Program Studi Pendidikan Sosiologi, Universitas Tanjungpura|iwan.ramadhan@untan.ac.id
}

Edy Agustinus

Badan Penelitian dan Pengembangan Provinsi Kalimantan Barat|idesunitas@yahoo.com

\section{A R T I C L E I N F O}

Article history:

Received

22 Mei 2021

Revised

20 Agustus 2021

Accepted

30 November 2021

Kata-kata Kunci:

Eksistensi adat; Hukum adat; Peran adat; Etnis dayak.

\section{Keywords:}

Customary existence;

Customary law; The role of adat; Dayak tribe.

\section{Abstrak}

Masyarakat Dayak di Kampung Bonsor Binua Sakanis Dae, hingga kini menggunakan adat sebagai instrumen penyelesaian sengketa ataupun persoalan sosial budaya. Penelitian ini bertujuan untuk mengungkapkan eksistensi adat dalam keteraturan sosial masyarakat Dayak di Kampung Bonsor Binua Sakanis Dae. Penelitian ini menggunakan pendekatan etnografis yang dilakukan dengan wawancara secara mendalam, observasi partisipatif dan juga pendokumentasian data dan informasi. Penelitian ini menunjukkan bahwa eksistensi adat sebagai sistem hukum di dalam kehidupan masyarakat di Kampung Bonsor Binua Sakanis Dae tampak dalam empat fenomena (1) diakui adat sebagai sistem nilai dan hukum oleh masyarakat di Kampung Bonsor, (2) terdapatnya pola kepemimpinan tradisional yang terstruktur dalam bentuk Binua, (3) terdapatnya prosedur penyelesaian sengketa/permasalahan berupa baras banyu, buah tangah, tail, dan pati nyawa, dan (4) memiliki jangkauan yang bersifat teritorial genealogis yang berlaku berdasarkan wilayah adat.

\section{Abstract}

The Dayak community in the village of Bonsor Binua Sakanis Dae uses custom as a dispute resolution or socio-cultural problem. This study aimed to reveal the existence of adat in the social order of the Dayak community in the Bonsor Binua Sakanis Dae Village. This research used an ethnographic approach, which involved in-depth interviews, participatory observations, and also the documentation of data and information. This research shows that custom, as a legal system in the life of the people in Kampung Bonsor Binua Sakanis Dae, can be seen in four phenomena: (1) the custom is recognized by the people in Bonsor Village as a system of values and law, (2) it is shown in the existence of a structured traditional leadership pattern in the community form of Binua, (3) there are procedures for resolving disputes/problems in the form of baras banyu, buah tangah, tail, and starch of life, and (4) having a genealogical territorial range that applies based on customary areas. 


\section{PENDAHULUAN}

Artikel ini hendak mendiskusikan tentang eksistensi adat dalam perannya sebagai pengaturan kehidupan sosial Dayak di Kampung Bonsor Binua Sakanis Dae. Diskusi demikian memiliki relevansi teoretis dalam kaitan dengan konsep pluralisme hukum ${ }^{1}$ sebagaimana yang berkembang pada masyarakat Indonesia yang mengenal lebih dari satu sistem hukum. ${ }^{2}$ Pluralisme hukum menjadi ruang bagi eksistensi nilai-nilai budaya dan nilai-nilai sosial sebagai sistem hukum yang tumbuh dan berkembang dari diri masyarakat. ${ }^{3}$ Pluralisme hukum menjadi pendorong bagi masyarakat Indonesia untuk menyelesaikan sengketa di luar pengadilan dengan sistem hukum negara atau hukum positif. ${ }^{4} \mathrm{Hal}$ ini terjadi terutama karena masyarakat Indonesia memiliki adat yang lebih mengutamakan musyawarah untuk mufakat ${ }^{5}$, serta menghindari pertikaian dalam menyelesaikan masalah. ${ }^{6}$ Fenomena ini menampakkan eksistensi peradilan adat sebagai realita yang masih terus dipraktekkan di tengah masyarakat Indonesia. ${ }^{7}$

Selain itu, artikel ini juga memiliki relevansi dalam kaitan dengan ilmu hukum dan sistem hukum baik pada skala makro pun mikro. Pada skala makro, relevan dalam kaitan dengan "penemuan the living law" mengingat the living law adalah salah satu komponen sistem hukum Indonesia. Penemuan the living law ini mengingatkan pada fakta bahwa keberadaan hukum adat benar-benar diakui dan dilaksanakan oleh masyarakat Indonesia. Penemuan adat sebagai living law menegaskan bahwa bangsa Indonesia menerapkan lebih dari satu sistem hukum atau dikenal dengan sistem hukum yang plural. ${ }^{8}$

Sementara itu, pada skala mikro, memiliki relevansi dengan isu pengakuan masyarakat adat dan adat istiadatnya. ${ }^{9}$ Pengakuan otoritas negara terhadap hukum adat dapat memperkuat kekhasan masyarakat adat dan sistem hukum adat, terutama karena adat telah menjadi landasan normatif dalam yurisprudensi.10 Artikel ini menunjukkan keberlakuan hukum adat dari masyarakat tertentu, terutama etnis Dayak dan keberadaan tersebut harus didukung komitmen konstitusional sebagai penghormatan terhadap hak-hak masyarakat hukum adat. Artikel ini juga memiliki relevansi dalam pembahasan tentang hak-hak masyarakat

$1 \quad$ Novita Dewi Masyithoh, 'Dialektika Pluralisme Hukum: Upaya Penyelesaian Masalah Ancaman Keberagaman dan Keberagamaan di Indonesia' (2016) 24 (2) Walisongo: Jurnal Penelitian Sosial Keagamaan 359.

2 Joeni Arianto Kurniawan, 'Pluralisme Hukum dan Urgensi Kajian Socio-Legal Menuju Studi dan Pengembangan Hukum yang Berkeadilan Sosial' (2012) 27 (1) Yuridika 17.

3 Nandang Sambas, 'Eksistensi Hukum Pidana Adat dalam Pembentukan Hukum Pidana Nasional' (2009) 11 (3) Syiar Hukum: Jurnal Ilmu Hukum 233.

$4 \quad$ Airil Safrijal, 'Penerapan Sanksi Adat dalam Penyelesaian Perkara Pidana di Kabupaten Nagan Raya' (2013) 15 (1) Kanun Jurnal Ilmu Hukum 145.

$5 \quad$ Herlambang P. Wiratraman, 'Perkembangan Politik Hukum Peradilan Adat' (2018) 30 (3) Mimbar Hukum 490.

6 Herlambang, 'Membangun Asas-asas Peradilan Adat (Studi pada Masyarakat Rejang dan Masyarakat Melayu Bengkulu)' (2012) 14 (1) Kanun Jurnal Ilmu Hukum 85, 87.

$7 \quad$ Yanis Maladi, 'Eksistensi Hukum Adat dalam Konstitusi Negara Pasca Amandemen' (2010) 22 (3) Mimbar Hukum 450.

8 Sulistyowati Irianto, 'Sejarah dan perkembangan pemikiran pluralisme hukum dan konsekuensi metodologisnya' (2003) 33 (4) Hukum dan Pembanguan 485.

9 Jawahir Thontowi, 'Perlindungan Dan Pengakuan Masyarakat Adat dan Tantangannya dalam Hukum Indonesia' (2013) 1 (20) Jurnal Hukum Ius Quia Iustum 21.

10 Enrico Simanjuntak, 'Peran Yurisprudensi dalam Sistem Hukum di Indonesia' (2019) 16 (1) Jurnal Konstitus 83. 
adat untuk mengatur kehidupan mereka menurut hukum adat mereka sendiri.11 Artikel ini juga mempromosikan pandangan yang lebih terbuka terhadap eksistensi adat sebagai sistem hukum yang hidup hingga masa kontemporer.

Menggunakan kajian etnografis dengan perpektif antropologi hukum, artikel ini membahas konsep adat sebagai hukum adat yakni suatu akumulasi atau abstraksi dari norma-norma dan kebiasaan-kebiasaan yang dianut masyarakat. Mengacu pada konsep adat dalam perpektif hukum, artikel ini memuat 3 bagian pokok yakni adat sebagai hukum adat, adat dalam keteraturan sosial, dan eksistensi adat dalam sistem hukum pada etnis Dayak di Kampung Bonsor Binua Sakanis Dae. Adat sebagai sistem hukum pada masyarakat tradisional, bukan semata karena sistem sanksi yang terdapat pada adat, namun karena perannya yang mampu menciptakan keteraturan sosial dan keharmonisan semesta. Artikel ini memberikan gambaran yang kontekstual terkait peran adat dalam kehidupan sosial budaya etnis Dayak di Kampung Bonsor Binua Sakanis Dae. Gambaran yang kontekstual ini berisi bentuk lembaga tradisional yang mengatur adat, peran para pengurus adat, proses pengadilan adat, serta prinsip dan makna hukuman yang memiliki fungsi sebagai pengendali kehidupan sosial. Secara kontekstual, adat mengalami eksistensi sebagai "the living law" yang dijiwai dan menjiwai seluruh kehidupan etnis Dayak di Kampung Bonsor Binua Sakanis Dae sebagai kesatuan hukum yang teritorial genealogis.

\section{PEMBAHASAN}

\section{Adat sebagai Hukum Adat}

Adat dan tradisi yang didasarkan pada pengalaman dan praktik kehidupan masyarakat menjadi sumber keteraturan dan keharmonisan sosial dan membentuk hukum adat. ${ }^{12}$ Pada dasarnya adat bukanlah hukum, tetapi beberapa kebiasaan akhirnya diubah menjadi hukum adat, yang jika diterima secara formal, diintegrasikan ke dalam hukum negara bahkan menjadi sumber hukum yang signifikan. Kenyataan diakuinya adat sebagai sumber hukum dalam sistem hukum negara tentu saja merupakan persoalan yang sangat penting bagi masyarakat tradisional dan konsepsi hukum adatnya. Bagi mereka, sangat penting untuk memiliki hak adat mereka, yang sebagian besar tidak tertulis, dipahami dan diakui sebagai sumber keteraturan dan keharmonisan yang memadai.

Adat mencerminkan keadilan yang restoratif dalam bentuk hukum yang asli dan memerlukan pengakuan oleh pihak eksternal, terutama otoritas negara. Pengakuan keadilan restoratif ini memperkuat adat sebagai sistem hukum dan mendorong eksistensinya di tengah pemiliknya. Adat dalam bentuk seperangkat aturan, nilai, dan tradisi yang secara umum diterima sebagai standar dan prosedur penyelesaian perkara terus digunakan dan dipertahankan oleh masyarakat, seperti pada masyarakat Sentolo Kabupaten Kulonprogo Yogyakarta, ${ }^{13}$ Hukum adat di

11 Yuliana Primawardani, 'Perlindungan Hak Masyarakat Adat dalam Melakukan Aktivitas Ekonomi, Sosial dan Budaya Di Provinsi Maluku' (2017) 8 (1) Jurnal HAM 1.

12 Robert D. Cooter dan Wolfgang Fikentscher, 'Indian Common Law: The Role of Custom in American Indian Tribal Courts (Part II of II)' (1998) 46 (3) American Journal of Comparative Law 509.

13 Agus Sudaryanto dan Sigid Riyanto, 'Eksistensi delik adat di lingkungan masyarakat Sentolo, 
Aceh ${ }^{14}$ yang menjadi cikal bakal hukum nasioal. ${ }^{15}$ Penggunaan nilai-nilai dan norma dalam masyarakat untuk menyelesaikan persoalan sosial-budaya pada masyarakat inilah yang oleh sebagian sarjana disebut hukum adat sebagaimana diungkapkan oleh Veronika Kusumaryati, ${ }^{16}$ Djaren Saragi ${ }^{17}$ juga Iman Sudiyat. ${ }^{18}$

Adat menjadi pilihan dalam menyelesaikan persoalan sosial budaya pada berbagai masyarakat di Indonesia, seperti digunakanya hukum adat sebagai alternatif sanksi terhadap pelaku kejahatan di Lhoksukon, Aceh Utara ${ }^{19}$, penerapan sanksi adat pada laki-laki yang melecehkan seorang wanita dengan melarikan dan melakukan kawin lari tanpa sepengetahuan dan seizin orang tua pada masyarakat Negeri Luhu, ${ }^{20}$ penerapan sanksi adat dalam penyelesaian perkara pidana di Kabupaten Nagan Raya Aceh, ${ }^{21}$ eksistensi delik adat di lingkungan masyarakat Sentolo, Kabupaten Kulonprogo Yogyakarta. ${ }^{22}$ Nilai-nilai tradisional pada adat sasi di Maluku yang menjadi hukum dalam peraturan sumber daya, ${ }^{23}$ juga seperti eksistensi masyarakat adat di Desa Bentenan Kecamatan Pusomaen Kabupaten Minahasa Tenggara menunjukan penguatan status Desa Bentenan menjadi Desa Adat. ${ }^{24}$ Fenomena ini menunjukkan keberadaan adat-istiadat sebagai identitas budaya serta warisan nenek moyang yang masih eksis di negara Indonesia.

Adat sebagai sistem hukum adat membutuhkan konsensus dan kesepahaman bersama tentang nilai-nilai yang baik dan benar yang termanifestasi dalam perilaku yang dapat diterima. Adat sebagai sistem hukum adat memiliki sifat sosial, yang terus menerus ditegaskan sebagai fakta hukum yang tidak tertulis dan berbeda dengan hukum resmi negara. ${ }^{25}$ Adat dipahami sebagai sistem hukum adat karena sifatnya yang menghasilkan aturan normatif, meskipun beberapa sarjana di Indonesia mengidentifikasi adat menjadi hukum adat karena aspek sanksi pada adat. ${ }^{26}$ Namun konsep sanksi pada adat terutama pada masyarakat di Nusantara bukanlah hal yang tepat sebagai indikator dalam memilih adat dari hukum adat. ${ }^{27}$

Kabupaten Kulonprogo Yogyakarta' (2016) 28 (1) Mimbar Hukum 46.

Kurniawan, 'Eksistensi masyarakat Hukum Adat dalam Lembaga-lembaga Adat di Aceh dalam Penyelenggaraan Keistimewaan dan Otonomi Khusus di Aceh' (2012) 1 (3) Yustisia 48.

M. Saleh, 'Eksistensi Hukum Adat dalam Polemik Hukum Positif suatu Kajian Dalam Perpektif Tata Negara' (2013) 1 (3) Kajian Hukum dan Keadilan 536.

Veronika Kusumaryati, 'Adat Institutionalisation, the State and the Quest for Self-Determination in West Papua' (2019) 21 (1) Asia Pacific Journal of Anthropology 1.

Djaren Saragih, Hukum Adat Indonesia (Tarsito 1996) 13.

Iman Sudiyat, Asas-Asas Hukum Adat (Liberty Yogyakarta 1981) 102.

Muhammad Yunus Ahmad, 'Sanksi Adat sebagai Hukum Alternatif terhadap Bandar Narkoba di Kecamatan Lhoksukon, Aceh Utara' (2017)19 (2) Substantia 199.

Ismail Kaliki, 'Perkawinan dan Sanksi Adat pada Masyarakat Negeri Luhu' (2016) 12 (2) Tahkim 21,31 .

Safrijal (n 4).

Sudaryanto dan Riyanto (n 13).

Reimon Supusesa, 'Eksistensi Hukum Delik Adat dalam Perspektif Pembaharuan Hukum Pidana di Maluku Tengah' (2012) 24 (1) Mimbar Hukum 41, 42.

Nur Apri Ramadan L. Usman, 'Eksistensi Masyarakat Hukum Adat dalam Penguatan Desa Adat di Desa Bentenan Kabupaten Minahasa Tenggara' (2015) 3 (7) Lex et Societatis 121.

Sulaiman, 'Mereposisi Cara pandang Hukum Negara terhadap Hukum adat di Indonesia' (2017) 2 (1) Petita 31.

Keebet von Benda-Beckmann, 'Anachronism, Agency, and the Contextualisation of Adat: Van Vollenhoven's Analyses in Light of Struggles Over Resources' (2019) 20 (5) Asia Pacific Journal of Anthropology 397.

Efriani dan Edy Agustinus, 'Reflection Of The Concept Of Sations And Law On The Tamambaloh Dayak Custom’ (2021) 23 (2) Kanun Jurnal Ilmu Hukum 309. 
Mengidentifikasi adat sebagai hukum adat haruslah menggambarkan konteks yang tepat di mana sistem hukum itu muncul dan digunakan.

Hukum adat sebagai sistem norma biasanya muncul di arena informal, menjadikan hukum adat sebagai faktor penentu dalam pengambilan keputusan hukum. Dalam masyarakat tanpa sistem hukum formal, adat menciptakan aturan, dan menuntut setiap perilaku sesuai dengan adat sehingga kehidupan itu sendiri menciptakan sistem hukum adat. Hukum adat merupakan elemen budaya yang vital, instrumen yang berhubungan dengan norma yang mengatur perilaku. Adat sebagai hukum adat tidak hanya didasarkan pada aspek sanksi pada adat, namun dilaksanakannya adat sebagai praktek keteraturan sosial yang diakui oleh setiap orang, menjadi kebiasaan dan merupakan bagian dari tradisi. Adat menjadi seperangkat aturan yang normatif sebagai peletak dasar dalam berperilaku.

\section{Adat Dalam Keteraturan Sosial di Kampung Bonsor Binua Sakanis Dae}

Berbicara gejala hukum dalam kehidupan masyarakat yang sederhana telah lama menjadi perdebatan dalam studi antropologi, khususnya antropologi hukum. Diantaranya terdapat para antropolog seperti Robert Redfield bahwa pada masyarakat yang sederhana tidak dijumpai sistem hukum yang rumit, namun terdapat aturan-aturan perilaku yang mencerminkan bentuk hukum. ${ }^{28}$ Namun terdapat juga pemikiran dari Radcliffe-Brown yang mengidentifikasi bahwa hukum hanya ditemukan pada masyarakat yang bernegara namun tidak pada masyarakat yang sederhana. ${ }^{29}$ Fenomena masyarakat dan gejala hukum merupakan konsep yang kompleks mengacu pada aspek ekologi, etno-politik, etno-hukum, dan juga budaya, merupakan kombinasi kebiasaan dengan seperangkat persepsi hukum yang dimiliki masyarakat dalam budaya tertentu. ${ }^{30}$ Dalam konsep ini hukum adat dipahami sebagai aturan berbasis pengetahuan tradisional tentu memiliki sifat yang diamis. Hukum adat bersumber pada adat, yang merupakan pengetahuan dan praktik bersama yang memiliki relevansi dan kekhususan budaya. Melalui adat, segala kebiasaannya ditransmisikan secara lisan, dipertahankan dan dilaksanakan, dan menjadi sistem aturan yang normatif.

Pada artikel ini, gejala-gejala hukum dalam adat masyarakat di kampung Bonsor, dikaji dalam latar budaya dan persepsi mereka tentang keteraturan sosial dan keharmonisan. Tulisan ini berpijak pada argumen bahwa dalam setiap masyarakat baik dalam bentuk negara pun dalam bentuk yang tradisional, mereka memiliki gejala hukum. Adat dalam hal ini dipandang sebagai seperangkat aturan yang mencerminkan bentuk hukum yang memiliki peran sebagai pengendali keteraturan sosial budaya. Aspek hukum dalam adat merupakan fenomena adat dalam persepsi hukum yang didasarkan pada pengetahuan dan pengalaman tradisional kehidupan masyarakat Dayak di Kampung Bonsor.

28 Robert Redfield, The Primitive World and Its Transformation (ed. 11, Cornell University Press 1969) 64-91.

29 Hilman Hadikusumah, Pegantar Antropologi Hukum (ed. 2, PT. Citra Aditya Bakti 2004$) 47$.

30 Tom G. Svensson, 'On Customary Law: Inquiry into an Indigenous Rights Issue' (2003) 20 (2) Acta Borealia 95. 
Dalam upaya mengkaji keteraturan sosial etnis Dayak di Kampug Bonsor ini, penulis melakukan wawancara, ${ }^{31}$ terhadap Timanggong Binua ${ }^{32}$ Sakanis Dae, Kepala Desa Tolok, Kepala Dusun Bonsor, Pangaraga ${ }^{33}$ dan Pasirah ${ }^{34}$ Kampung Bonsor. Kepada para informan, diajukan pertanyaan terkait dengan adat yang digunakan dalam proses penyelesaian masalah. Pertanyaan pada wawancara ini secara garis besar dimaksudkan untuk mengungkapkan pola kepemimpinan lokal atau tradisional yang terdapat di Kampung Bonsor serta tata cara atau proses penyelesaian persoalan yang terjadi di tengah masyarakat. Setiap peserta diwawancarai dalam sesi wawancara mendalam semi-terstruktur yang berlangsung dari 50 hingga 100 menit dengan tujuan untuk memberikan kesempatan kepada para informan dapat secara bebas mendeskripsikan hal yang penting bagi mereka terkait degan adat dan keteraturan sosial. Selanjutnya, hasil wawancara ditranskrip ke dalam catatan lapang sesuai dengan versi asli percakapan tersebut. Pengalaman hidup hingga hukum adat yang berlaku dideskripsikan sesuai makna dan kaidah budaya etnis Dayak di Kampung Bonsor.

Pada wawancara yang lakukan terhadap Kepala Desa Tolok, diperoleh informasi bahwa umumnya etnis Dayak memiliki sistem kepemimpinan tradisional yang dikenal dengan sebutan Binua .

"orang Dayak itu punya sistem kepemimpinan tradisional, yang biasanya disebut binua atau banua, dipimpin oleh seorang kepala binua yang disebut Timanggong atau ada juga yang menyebutnya Timanggung atau Tamanggung. Kalau orang Dayak Kananyant di sini, namanya binua, dikepalai oleh seorang Timanggong. Tiap-tiap Timanggong itu, dipilih atau diangkat oleh masyarakat secara langsung. Kriteria seorang Timanggong itu harus punya pengetahuan dan pengalaman terkait adat istiadat, bijaksana dalam menyelesaikan suatu perkara. Tanggung Jawab utama mereka adalah menjaga ketenteraman kehidupan bersama, termasuk mendamaikan orang-orang yang bertikai. "35

Khusus untuk Kampung Bonsor, berada di bawah Ketimanggongan Binua Sakanis Dae. Wilayah adat di Binua Sakanis Dae dipimpin oleh seorang Timanggong yang membawahi kampung pada tingkat dusun. Pada tingkat dusun, juga terdapat struktur pimpinan adat yang menjalankan tugas secara berjenjang yakni, Kepala Adat, Pasirah, dan Pangaraga. Struktur kepemimpinan adat ini menjadi satu organisasi sosial di Binua Sakanis Dae yang menjalankan fungsi dan peran untuk mengatur hal-hal yang berhubungan dengan adat istiadat dan ketenteraman kampung, termasuk menyelesaikan konflik atau perkara. Organisasi ini terbentuk secara alamiah sesuai kebudayaan dan tradisi nenek moyang, telah disepakati secara bersama, khususnya dalam perannya sebagai "lembaga" hukum. Struktur kepempimpinan adat dalam mengurus hukum dan sanksi adat dibentuk guna menyelesaikan setiap perkara adat mulai dari perkara kecil atau ringan hingga perkara besar atau berat yang dilaksanakan secara berjenjang, sebagaimana tampak pada gambar di bawah ini.

31 John W. Creswell, Research Design: Qualitative, Quantitative, and Mixed Methods Approaches (ed. 3, SAGE Publications Inc. 2009) 136.

32 Timanggong merupakan pemimpin tertinggi pada suatu kawasan berdasarkan kesatuan adat. Kesatuan adat dikenal dengan binua.

Pangaraga merupakan fungsionaris adat yang berada pada tingkat pertama

Pasirah fungsionaris adat pada tingkat kedua

Wawancara dengan Supardi, Kepala Desa Tolok (Bosor, 11 April 2021). 


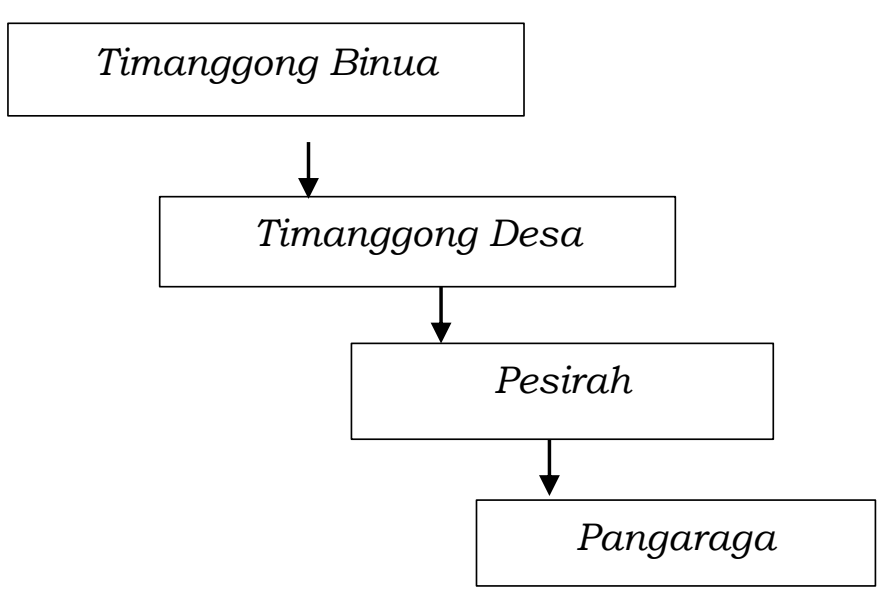

Bagan 1.

Struktur kepemimpinan adat dalam mengurus hukum berdasarkan sanksi adat.

Melalui wawancara juga diperoleh informasi bahwa organisasi tradisional yang dikenal dengan Binua ini, menjalankan fungsi sebagai lembaga penyelesaian masalah dan sengketa, yang dilakukan secara berjenjang.

"Kita ini berada dalam Ketimanggongan Binua Sakanis Dae, sehingga adat yang kita gunakan juga berbeda dengan adat yang berlaku pada Ketimanggongan Binua Sakanis Aek. Perbedaan yang sangat menonjol lebih kepada nilai peletakkan sanksi adat, peletakkan nilai sanksi adat Sakanis Air (Sakanis Aek) lebih besar karena perkara yang melebihi ketentuan adat $1 \frac{1}{2}$ tail, ${ }^{36}$ diharuskan membayar adat yang dinamakan "kepala siam"37, peraganya berupa tempayan besar banyanyi atau jampa ${ }^{38}$ dan pahar. ${ }^{39}$ Sedangkan pada nilai peletakkan sanksi adat Sakanis Darat (Sakanis Dae) dinamakan "kepala siam" tersebut hanya akan ditebus pada saat seseorang melakukan perkara yang sangat berat hingga menyebabkan korban sampai meninggal dunia, adat ini disebut "adat pati nyawa". Ketentuan dengan nilai adat yang melebihi $3 \frac{1}{2}$ tail maka pengurus perkara adat ini bukan lagi Pasirah, Pangaraga ataupun Kepala Adat melainkan Timanggong Desa." 40

Dengan demikian dapat disimpulkan bahwa proses penyelesaian masalah/sengketa pada organisasi ini, merupakan suatu peradilan adat yakni suatu proses atau tata cara dalam menangani serta menyelesaikan perkara atau sengketa sesuai dengan adat-istiadat yang berlaku pada satu wilayah secara khusus.

Dalam wawancara dengan seorang tokoh adat Kampung Bonsor, diungkapkan bahwa, terdapat beberapa orang yang menjalankan peran sebagai tokoh adat yang menangani persoalan atau permasalah yang terjadi di kampug Bonsor.

"Bonsor ini Kampung, terdapat banyak sekali adat yag diurus oleh beberapa orang, mulai dari Timanggong Binua Sakanis, Timanggong Desa, Kepala Adat, Pasirah dan Pangaraga. Seorang Timanggong mengurus satu Binua, namun terdapat pula Timanggong yang mengurus wilayah adat Desa disebut Timanggong Desa. Di Bawah Timanggong, setingkat dusun atau kampung terdapat Kepala Adat, Pasirah dan Pangaraga. Jadi dalam menjalankan tugasnya, seorang Timanggong Binua dibantu oleh Timanggong Desa, Kepala Adat, Pesirah dan Pangaraga. Tapi, masing-masing

\footnotetext{
36 Satuan hukum yang digunakan untuk menentukan adat yang wajib dibayarkan.

37 Nama adat yang dikenakan/sanksi pada pelanggaran adat.

38 Tempayan antik yang bergambarkan naga.

39 Baki besar berkaki terbuat dari kuningan umumnya digunakan untuk menyajikan makanan.

40 Wawancara dengan Firdaus, Timanggong Desa Tolok Sakanis Dae (Ojak, 13 April 2021).
} 
dari mereka, memiliki wilayah jangkauan yang terbatas, berdasarkan besaran suatu masalah yang terjadi." ${ }^{41}$

Kepengurusan adat di Binua Sakanis Dae mencerminkan suatu bentuk sistem hukum yang memiliki peran untuk mengatur hal-hal yang berhubungan dengan adat-istiadat, nilai dan norma yang digunakan sebagai pedoman untuk bersikap dan bertingkah laku. Sistem hukum ini bersifat mengikat setiap anggota atau masyarakat Kampung Bonsor, berlaku secara nyata dan rata. Kepengurusan adat ini, memiliki kewenangan penuh dalam menjaga keharmonisan dan ketertiban masyarakat, digunakan sebagai cara dalam menyelesaikan setiap persoalan yang terjadi.

Penyelesaian masalah dilakukan secara berjenjang, berdasarkan pada berat dan ringannya suatu permasalahan, sehingga para pengurus adat Binua Sakanis Dae merupakan organ-organ yang menjalankan fungsi peradilan adat. Adapun organ-organ tersebut adalah:

(1) Pangaraga

Pangaraga merupakan organ adat yang berada pada tahap pertama, berhak dan wajib menangani setiap perkara adat, dari buah tangah hingga ke 11/2 tail. Dalam kehidupan sosial budaya masyarakat Dayak di Kampung Bonsor Binua Sakanis Dae, seorang Pangaraga menyelesaikan pelanggaran adat atau perselisihan yang bersifat ringan. Apabila pada organ pertama ini, adat tidak dapat diselesaikan, maka akan naikkan pada jenjang yang lebih tinggi di atas Pangaraga yakni Pasirah. Dalam kasus yang demikian, Pangaraga berperan membantu Pasirah dalam menyelidiki kejadian-kejadian yang akan diproses secara adat pada organ kedua.

(2) Pasirah

Fungsionaris adat pada tahap kedua adalah Pasirah, bertugas untuk menangani perkara adat yang tidak dapat terselesaikan pada tingkat bawah atau di Pangaraga. Seorang Pasirah menangani permasalahan pada sanksi 11/2 tail - 31/2 tail. Apabila keputusan adat yang sudah ditangani oleh Pasirah juga belum dapat diterima, maka akan diajukan dan ditangani oleh kepala adat. Kedudukan Pasirah umumnya berada di kampung, perannya adalah membantu Timanggong untuk menangani perkara adat di kampungnya.

(3) Timanggong Desa

Timanggong Desa merupakan fungsioaris adat yang menyelesaikan perkara dari 3 $1 \frac{1}{2}$ tail - 6 tail. Seorang Timanggong Desa sebagai pemimpin adat yang membawahi kampung atau dusun yang memiliki hak dan kewajiban untuk menyelesaikan perkara apabila perkara tersebut tidak dapat terselesaikan oleh Pangaraga dan Pasirah. Selanjutnya apabila perkara belum juga terselesaikan, maka akan ditanggani ke jenjang organ adat tertinggi di tingkat Binua yakni Timanggong Binua.

(4) Timanggong Binua

Seorang Timanggong Binua membawahi satu wilayah kekuasaan adat pada tingkat Binua yang umumnya mencakup lebih dari satu kecamatan. Satu wilayah adat yang disebut Binua ini terdiri atas kampung-kampung, sehingga di dalam menjalankan tugasnya seorang Timanggong Binua dibantu oleh

41 Wawancara dengan Martinus Ude, Pasirah Kampung Bonsor (Bonsor, 13 April 2021). 
Timanggong Desa, Pasirah dan Pangaraga. Timanggong Binua menangani perkara dari 6 tail - 12 tail, dan bila adat tidak dapat terselesaikan pada tingkat Binua, maka selanjutnya perkara dinaikkan pada tingkat yang lebih tingggi yakni dewan adat dayak.

(5) Dewan Adat Dayak (DAD)

Pada tingkat yang lebih tinggi, umumnya lintas Ketimanggongan, terdapat DAD, yang tingkatannya berada pada level kabupaten bahkan juga pada tingkat provinsi. Terdapat perbedaan fungsi antara kepengurusan Timanggong, Pasirah dan Pangaraga tersebut dengan DAD. Timanggong, Pasirah dan Pangaraga berfungsi sebagai penegak norma adat atau "hakim" yang menjaga keharmonisan di wilayah Binuanya. Sementara itu, DAD fungsinya lebih kepada usaha-usaha untuk memberdayakan, melestarikan, dan mengembangkan adat istiadat masyarakat Dayak agar semakin dikenal dan menjadi bagian dari pergaulan mulai dari skala lokal, nasional bahkan internasional. Selain itu DAD juga memiliki fungsi untuk melakukan koordinasi, komunikasi, pelayanan, pengkajian dan wadah menampung dan menindaklanjuti aspirasi masyarakat dan semua lembaga Adat Dayak. ${ }^{42}$

Selain melakukan wawancara, artikel yang bersumber dari penelitian ini juga menggunakan teknik non-verbal yakni observasi perilaku. ${ }^{43}$ Selama tiga bulan penelitian ini berlangsung antara Februari hingga Mei 2021, dilakukan pengamatan secara langsung terhadap pola kehidupan sosial masyarakat Kampug Bonsor. Pengamatan dilakukan terhadap perilaku mereka, terutama persepsi dan pengalaman mereka tentang adat. Kehidupan sosial yang kami amati sangat berhubungan erat degan kehidupan mata pencaharian masyarakat Bonsor yang sebagian besar diklasifikasikan sebagai kelas pekerja pada bidang pertanian dan berternak babi. Pola mata pencaharian ini menjadikan mereka memiliki ikatan yang erat dengan lingkungan alam di sekitar mereka. Secara geografi, Kampung Bonsor berada di bagian ujung Kecamatan Manyuke. Daerah ini mencakup mayoritas masyarakat keturunan dari suku Dayak Kanayant. Selama proses penelitian berlangsung, peneliti berbaur dan menyatu dengan masyarakat kampung Bonsor, tinggal di rumah salah satu tokoh masyarakat.

Meskipun, selama penelitian ini berlangsung, tidak terdapat proses peradilan adat, namun dalam kunjungan kami ke kediaman Kepala Dusun Bonsor, diperoleh satu kisah tentang proses penyelesaian sengketa yang pernah dan telah dilakukan dengan adat.

"Adat hanya digunakan pada perkara yang mendapat sanksi tidak lebih dari 24 tail. Apabila saksi yang dikenakan terhadap pelanggaran atau suatu sengketa melebih 24 tail, bisa dijatuhkan sanksi pidana, dan proses penyelesaian masalah diserahkan kepada hukum negara. Namun demikian, 24 tail bukan satu-satunya ukuran untuk menjatuhkan hukuman pidana terhadap suatu masalah. Beberapa pelanggaran adat dapat berlaku pidana jika dilakukan berulang-ulang. Seperti seseorang melakukan pencurian sudah lebih dari 3 kali atau bahkan lebih, maka kami akan melimpahkan kasus ini kepada Pangaraga, jika Pangaraga tidak sanggup juga, ya kami limpahkan

42 Edy Agustinus dan Herkulana Mekarryani, Penerapan Kearifan Lokal Adat Balala dalam 'pencegahan Penyebaran Pandemi Covid-19 di Kabupaten Landak' (Kristianus Atok dan Efriani ed. Derwati Press 2021) 58.

43 Martono, dkk, 'The National Identity On The Border : Indonesian Language Awareness And Attitudes Through Multi Ethnic Community Involvement' [2021] Journal Community Psychology 1. 
kepada Timanggong desa itu sekitar 6 tail - 24 tail, jika tidak sanggup juga berarti kadar kejahatan yang dilakukan itu sudah keterlaluan. Nah, kasus ini kami limpahkan kepada kepala desa dan pihak yang berwajib yaitu kepolisian.

Ini saya ceritakan satu contoh, biar kita semua bisa memahami. Ini terjadi di rumah saya, pada saat itu ada yang berkonflik tanah warisan, diantara dua orang adik dan kakak, mereka berkelahi di rumah saya sampai tinju-tinjuan dan keluar darah. Karena mereka berkelahi di rumah saya, hingga mengeluarkan darah, maka mereka dikenakan adat nanum. Alat peraga adatnya berupa ayam satu ekor, baras banyu, satu singkap pinggan (satu buah piring) kemudian dilakukan makan bersama dengan sanksi, pengurus dan orang yang diadat. Kemudian sesudah membayar adat nanum, mereka masih tetap menuntut untuk diselesaikan oleh pangaraga. Namun, salah seorang dari mereka bersikeras untuk menyelesaikan perkara ini ke kepolisian untuk dipenjarakan, sehingga kasus ini tidak dapat diselesaikan di pangaraga. Karena hal itu, kemudian Pangaraga melimpahkan perkara itu ke Pasirah, karena keduanya saling tidak mengakui kesalahan sehingga dikenakan saksi $1 \frac{1}{2}$ tail sampai $3 \frac{1}{2}$. Namun karena keduanya menolak untuk diselesaikan oleh Pasirah, kemudian Pasirah menaikkan sanksinya hingga ke Timanggong Desa. Namun keduanya masih bersikeras untuk menyelesaikan permasalah melalui jalur pidana. Akan tetapi, Timanggong masih memberikan kesempatan agar permasalah ini dapat diselesaikan secara kekeluargaan, musyawarah dan damai, sehingga permasalahanpun dikembalikan oleh Timanggong kepada Pasirah, dan keduanya mendapat sanksi adat $3 \frac{1}{2}$ tail." 44

Hasil wawancara tersebut mengindikasikan fungsi adat pada masyarakat Bonsor melekat dan tidak terpisahkan. Masyarakat di Bonsor lebih memilih melaksanakan hukum adat yang berlaku dibandingkan menyerahkan kasus ini langsung kepada pihak kepolisian. Norma dan adat yang diyakini masyarakat lebih mendongkrak moral dan kesadaran mereka untuk tidak melakukan tindakan yang menyebabkan sanksi. Kasus ini juga berkaitan dengan apakah hukuman yang dijatuhkan pada pelaku tersebut cukup untuk membayar tindak kejahatannya dan apakah masalah ini memerlukan pertimbangan dalam menentukan hukuman yang berkepanjangan atau tidak. Pasirah, Pangaraga dan Timanggong desa dalam hal ini telah menerima 'bukti ahli dan meyakinkan' tentang kronologis sebuah kasus yang harus mereka selesaikan. Adat yang berlaku di Bonsor membuktikan bahwa pertimbangan keputusan dalam penentuan kasus hukum harus berdasarkan pertimbangan dari tokoh adat.

Dengan memperhatikan data-data lapangan tersebut, tampak pola kepemimpinan tradisional serta fungsi organisasi tersebut cenderung menggunakan adat-istiadat yang diwariskan secara turun-temurun dari leluhur mereka. Keputusan dalam penyelesaian sengketa dipegang oleh Timanggong sebagai kepala Binua, serta para pelaksana lainnya yang memiliki peran dalam binua dan kampung tersebut. Setiap keputusan merupakan keputusan bersama yang diambil berdasarkan adat-istiadat dan kebiasaan leluhur mereka. Setiap sanksi yang diberikan, dimaksudkan untuk pengendalian sosial serta menjaga keharmonisan semesta, sehingga sanksi itu sendiri tidak dimaknai sebagai hukuman, namun lebih sebagai suatu proses pengembalian nilai dan situasi. Hal ini tentu selaras dengan fungsi dan peran adat dalam kehidupan etnis Dayak pada umumnya.

Mengacu pada pendapat para ahli antropologi hukum, terutama yang memiliki pola pikir dengan jalur kiri, seperti Bronislaw Malinowski, ${ }^{45}$ adat pada masyarakat

44 Wawancara dengan Simu, Kepala Dusun Bonsor (Bonsor, 14 April 2021).

45 Hadikusumah (n 29) 47-50. 
Dayak di Kampung Bonsor, memiliki makna sebagai sarana pengendalian sosial (legal order). Pada fenomena seperti ini, antropolog memandang terdapatnya gejala hukum dalam kehidupan masyarakat bersahaja atau masyarakat sederhana. Adat sebagai gejala hukum terdapat dalam bentuk mekanisme-mekanisme yang diciptakan untuk menjaga keteratuan sosial atau sebagai sarana pengendalian sosial. Sistem Binua sebagai mekanisme dan struktur adat mencerminkan sistem hukum yang bagian-bagiannya tidak terpisah dari susunan masyarakat, bahkan tidak terbentuk dalam lembaga sendiri. Otoritas tertinggi dalam penyelesaian masalah berada pada Timanggung, sebagai kepala Binua. Namun perlu dicermati pula, bahwa masyarakat Dayak di Kampung Bonsor ini, memiliki keyakinan terhadap "otoritas abstrak" sebagaimana yang tercermin dalam kosmologi mereka. Dengan demikian, adat merupakan hukum yang hidup, benar-benar dijalankan oleh orang-orang yang "diperintahnya". Adat telah menjadi landasan normatif sejak jaman dahulu, dan terinternalisasi dalam kehidupan sosial budaya.

Fenomena Adat dalam keteraturan sosial di Kampung Bonsor Binua Sakanis Dae ini, memperluas cakrawala hukum yang tidak hanya keseimbangan dalam tatanan hukum di antara manusia, namun suatu realisasi keadilan dan keharmonisan antara manusia dengan bumi. Adat bagi kehidupan etnis Dayak memiliki fungsi yang sentral, yakni sebagai keseimbangan dan keharmonisan semesta. ${ }^{46}$ Adat menjadi medium yang mewujudkan keteraturan, mengendalikan dan memberi arah kepada sikap dan perbuatan manusia dalam kehidupan sosial dan budaya. ${ }^{47}$ Bagi orang Dayak di Kampung Bonsor Binua Sakanis Dae, orangorang yang bertingkah laku dengan melanggar adat, mereka akan disebut tidak beradat oleh karenanya setiap orang yang melanggar adat, akan dikenai sanksi adat. Fenomena ini memiliki kesesuaian dengan konsep adat sebagai aturan dan kebiasaan, dan tata kelakukan yang telah ditetapkan serta berlaku dan berfungsi untuk menuntun tingkat laku masyarakatnya.

\section{Eksistensi Adat dalam Sistem Hukum di Kampung Bonsor}

Adat yang memiliki sanksi oleh para sarjana hukum disebut sebagai hukum adat $^{48}$ yang hingga kini hidup dan berkembang di antar etnis-etnis di Nusantara. Dalam sejarah penyelidikan hukum adat di Indonesia, dimulai dengan fenomena sanksi pada adat-istiadat yang disebut memiliki gejala hukum. ${ }^{49}$ Gejala-gejala hukum itu kemudian disebut sebagai hukum asli masyarakat Indonesia, yang bersumber dari kebiasaan dan nilai-nilai dan seluruh kebudayaan bangsa Indonesia, ${ }^{50}$ tumbuh dan hidup dalam masyarakat Indonesia. ${ }^{51}$ Mencermati datadata etnografis tentang adat dan keteraturan sosial pada masyarakat Bonsor,

\footnotetext{
46 Efriani, 'Adat Suku Dayak Tamambaloh Sebagai Pengendali Sosial, Bukanlah Hukum Adat (Pengamatan Ontologis, Epistemologis Dan Aksiologis)' (Simposium Kebudayaan Indonesia Malaysia XIII, Bandung, 13 November 2013) 85.

47 Albert Rufinus dkk, Tradisi Lisan Dayak Yang Tergusur dan Terlupakan (S. Djuweng, N. Andasputra, J. Bamba, \& E. Petembang ed., Institute Dayakologi 2003) 59.

48 Soerjono Soekanto, Meninjau Hukum Adat Indonesia: Suatu Pengantar untuk Mempelajari Hukum Adat (Rajawali 1996) 5-9.

49 Koentjaraningrat, Metode Antropologi dalm Penyelidikan Masyarakat di Indonesia (sebuah iktisar) (Universitas Indonesia 1958) 322-325.

50 Koentjaraningrat, Sejarah Teori Antropologi I (Universitas Indonesia 1987)177-178.

51 Saragih (n 17).
} 
menunjukkan eksistensi adat dan nilai-nilai tersebut sebagai hukum yang berlaku hingga masa kini dalam kehidupan masyarakat di kampung Bonsor.

Eksistensi adat dalam keteraturan sosial etnis Dayak di Kampung Bonsor Binua Sakanis Dae dapat dijumpai pada:

(1) Diakuinya Adat sebagai Sistem Nilai dan Hukum

Sistem hukum pada masyarakat Bonsor merupakan ekspresi budaya yang dipahami oleh manusia secara fungsional yang berasal dari sistem kebudayaan nusantara. Sistem hukum tersebut merupakan wujud dari nilai-nilai budaya pada masyarakat Kampung Bonsor. Nilai-nilai budaya, menjadi hal yang esensial dan subtantif dalam keteraturan sosial budaya. Masyarakat kampung Bonsor, hingga kini mengakui bahwa adat merupakan nilai-nilai luhur yang harus dijunjung tinggi. Sehingga, adat menjadi aturan dan hukum yang mengatur kehidupan masyarakat secara adil dan harmonis sesuai dengan ketentuannya.

Pengamatan di lapangan menunjukan bahwa masyarakat Kampung Bonsor sudah memahami aturan adat yang berlaku sebagai pengendali kehidupan sosial. Masyarakat sangat percaya terhadap adat sebagai sistem hukum yang adil, di dalamnya terdapat keseimbangan dan perlindungan. Dalam hal ini keadilan tidak bisa dipahami sebagai suatu tindakan yang sama atau persamarataan, adil bukan berarti tiap-tiap orang akan memperoleh bagian yang sama, namun lebih pada memberikan hak dan kewajiban yang menjadi prioritas bagi setiap orang. Besar atau kecilnya hak dan kewajiban tersebut tidak dapat dipermasalahkan oleh siapapun. Oleh karena itu, penyelesaian sengketa secara adat hingga kini menjadi pilihan utama masyarakat di Kampung Bonsor.

(2) Terdapatnya Pola Kepemimpinan yang Terstruktur

Kehidupan komunal etnis Dayak ditandai dengan persekutuan pada satu bahasa dan satu Binua yang dipimpin oleh seorang Timanggong. Dengan demikian, ditemukan pola kepemimpinan tradisional yang terstruktur. Kepemimpinan seperti ini dapat dikategorikan pada kepemimpinan dengan tipe headship, yang kedudukan pemimpin dilakukan melalui pengangkatan dan pengakuan nyata serta penerimaan dari masyarakat yang dipimpin. Kriteria seorang Timanggong ialah memiliki pengetahuan tentang adat istiadat, memiliki kemampuan untuk memimpin, bijaksana dan mampu untuk berlaku adil. Seorang Timanggong sebagai kepala Binua Sakais Dae, memiliki legitimate power yang diakui oleh seluruh masyarakat di Binua Sakanis Dae serta menjadi simbol kesadaran dan identitas akan kesatuan kebudayaan. Seorang Timanggong merupakan perwujudan atau cermin dari kepribadian dan kehidupan bersama serta jiwa masyarakat yang dipimpinnya. Pola kepemimpinan ini, dijalankan dalam suatu struktur yang ditetapkan secara berjenjang. Jenjang pada struktur tersebut berdasarkan peran dan fungsi setiap aktor dalam menyelesaikan suatu sengketa atau permasalahan yang terjadi dalam masyarakat.

(3) Terdapatnya Prosedur Penyelesaian Sengketa/Permasalahan

Adat-istiadat di Kampung Bonsor juga memperlihatkan gejala hukum yang bercorak tradisional, yakni suatu sistem sosial yang diwarisi secara turun temurun, dan masih berlaku hingga sekarang. Adat ini memiliki sifat yang lekat dengan sistem kepercayaan etnis Dayak yang umumnya memiliki sistem kepercayaan animism. ${ }^{52}$ 
Bagi mereka adat merupakan suatu medium dalam menjaga keharmonisan dan keseimbangan semesta, termasuk di dalamnya hubungan antar sesama manusia, juga manusia dengan seluruh isi alam. ${ }^{53}$ Corak lain yang tampak dalam adat sebagai gejala hukum di Kampung Bonsor ialah sifatnya yang mengutamakan kepentingan bersama, musyawarah, kekeluargaan dan kedamaian. Adat menjadi realita yang konkret dalam kehidupan etnis Dayak di Kampung Bonsor, setiap tindakan dan tata kelakukan yang melanggar adat diukur dengan jelas sesuai adat-istiadat yang berlaku.

Adat sebagai pengaturan kehidupan sosial hingga kini masih dilaksanakan dan diyakini oleh orang-orang Dayak di Kampung Bonsor. Penyelesaian perkara atau masalah dilakukan dengan adat yang disesuaikan dengan besarnya perkara atau permasalahan yang akan diselesaikan. Adapun ukuran adat itu dimulai dari adat yang paling kecil hingga pada tindakan pidana, yakni baras banyu, buah tangah, tail, pati nyawa hingga tindakan pidana. Baras banyu merupakan adat yang kecil atau ringan, yakni beras yang dicampur dengan minyak kelapa atau minyak goreng, merupakan simbol permohonan ampun kepada mahkluk halus atas segala kesalahan dan kekhilafan. Sanksi adat buah tangah terdiri dari satu tempayan, satu buah mangkok dan satu ekor ayam. Sanksi adat untuk 1 tail terdiri dari satu pahar, satu tempayan, satu ekor ayam, satu buah mangkok, satu baras banyu dan satu pangkaras. Sanksi adat dengan hukuman tail dapat saja ditambah dengan yang disebut siam atau berkepala siam. Adat yang ditambahkan sanksi adat siam, dikategorikan pada pelanggaran adat yang berat, dapat berupa kasus asusila dan kasus berdarah. Siam merupakan peraga adat yakni tempayan berwarna hitam, bergambar naga yang disebut banyanyi. Siam dipakai pada sanksi adat 31/2 tail - 6 tail. Di atas 6 tail, dikenal lagi sanksi adat yang disebut kepala siam beranak mando (mandau), yakni satu buah tempayan (banyanyi) dan satu buah senjata adat Dayak (mandau). Pelanggaran adat yang sangat berat hingga menyebabkan korban nyawa atau sampai meninggal dunia disebut adat pati nyawa.

Dalam penyelesaian perkara melalui adat ini dilakukan pula secara berjenjang berdasarkan besaran sanksi adat yang dikenakan kepada pelaku pelanggar adat. Misalnya masalah pada dunia pertanian. Untuk masalah dengan sanksi baras banyu hingga ke buah tangah, diselesaikan pada tingkat kelompok tani oleh ketua tani. Perkara dari buah tangah hingga ke $1 \frac{1}{2}$ tail diselesaikan pada tingkat Pangaraga, dari $1 \frac{1}{2}$ tail - 31/2 tail pada tingkat Pasirah, 31/2 tail - 6 tail pada tingkat Timanggong desa, 6 tail - 12 tail pada Timanggong kecamatan, dari 12 tail - 24 tail pada tingkat DAD yang dilakukan melalui musyawarah adat (musdat), dan 24 tail dikategorikan tindakan pidana dan diadili dengan peradilan negara atau hukum negara.

Tabel. 1 Besaran Adat dan Tingkat Penyelesaiannya

\begin{tabular}{|l|l|l|}
\hline No. & \multicolumn{1}{|c|}{ Besaran sanksi/pelanggaran adat } & \multicolumn{1}{c|}{ Tingkat Pengurus } \\
\hline 1 & baras banyu - buah tangah & Kelompok/keluarga \\
\hline 2 & buah tangah $-1 \frac{1}{2}$ tail & Pangaraga \\
\hline
\end{tabular}

Jurnal Sosial dan Budaya 24.

53 Efriani, Budhi Gunawan dan K Garna Judistira, 'Kosmologi dan Konservasi Alam pada Komunitas Dayak Tamambaloh di Kalimantan Barat' (2019) 2 (2) Studi Desain 66. 


\begin{tabular}{|l|l|l|}
\hline 3 & $1 \frac{1}{2}$ tail $-3 \frac{1}{2}$ tail & Pasirah \\
\hline 4 & $3 \frac{1}{2}$ tail -6 tail & Timanggong Desa \\
\hline 5 & 6 tail -12 tail & Timanggong Binua \\
\hline 6 & 12 tail -24 tail & DAD (musdat) \\
\hline 7 & $\geq 24$ tail & Pidana (Hukum Negara) \\
\hline
\end{tabular}

Sumber; Wawancara, Kepala Dusun Bonsor, 2021

Gambar 1. Peraga adat Siam berupa "Banyanyi atau Jampa"

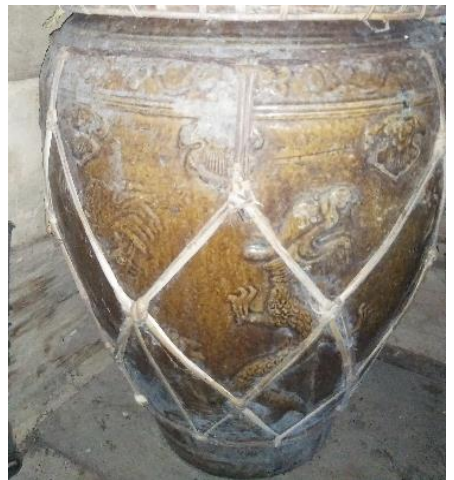

Gambar 2. Peraga adat berupa Pahar

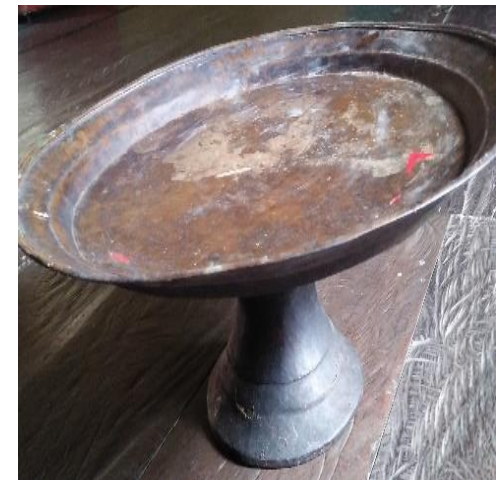

Sumber : Pengamatan Pribadi Penulis, 2021

(4) Memiliki Jangkauan yang Bersifat Teritorial Genealogis

Kampung Bonsor merupakan satu dusun yang tergabung ke dalam wilayah adat Binua Sakanis Dae (Sakanis Darat). Kata Binua dalam hal ini merujuk kepada area berlakunya norma dan sanksi adat. Satu Binua umumnya terdiri dari beberapa kampung, namun antara binua satu dengan binua lainnya tidak dapat saling mencampuri khususnya terkait dengan urusan adat istiadat. ${ }^{54}$ Binua Sakanis sendiri terdiri dari dua Binua, yakni Binua Sakanis Dae (Sakanis Darat) yang secara administratif kepemerintahan meliputi dua desa yakni Desa Sungai Lobang, Desa Tolok, dan Binua Sakanis Aek Air (Sakanis Air) yang wilayahnya meliputi Desa Anik dan Desa Bagak.

Secara administratif, Kampung Bonsor merupakan satu dusun, yakni Dusun Bonsor, di Desa Tolok, Kecamatan Menyuke, Kabupaten Landak, Provinsi Kalimantan Barat. Kampung Bonsor merupakan kampung yang berada paling ujung dari Binua Sakanis Dae karenanya kampung Bonsor dijuluki sebagai puncak batas Binua. Di dalam wilayah adat inilah, kehidupan sosial dan budaya orang-orang Bonsor diatur dalam keharmonisan dan kekeluargaan. Masyarakat Kampung Bonsor adalah etnis Dayak, yang berbahasa Banyadu' dan berbahasa Banana' dan umumnya dikenal dengan sebutan orang Bonsor. Saat penelitian ini berlangsung, peneliti mendapatkan data bahwa di kampung Bonsor terdapat 399 jiwa dengan jumlah 88 Kepala Keluarga.

Secara adat, masyarakat Kampung Bonsor terikat pada kesatuan masyarakat yang berbentuk paguyuban (rechtsgemeenschap) yang disebut Binua Sakanis Dae, sehingga setiap masyarakat sangat menjunjung tinggi adat sebagai sistem hukum 
secara tradisional. Adat-istiadat yang dimiliki oleh etnis Dayak di Kampung Bonsor merupakan persekutuan hukum genealogis teritorial. Secara genealogis, masyarakat kampung Bonsor mengakui ikatan kekerabatan yang berasal dari nenek moyang dan leluhur yang sama. Leluhur yang membawah mereka ke Kampung Bonsor, sehingga setiap anggota masyarakat Kampung Bonsor, mengakui adat yang berlaku di Kampung itu.

Sanksi pada adat di Kampung Bonsor merupakan adat yang berlaku di Binua Sakanis Dae, yakni suatu wilayah adat yang dipimpin oleh Timanggong. Adatistiadat dan ketentuannya berlaku bagi semua orang yang terikat oleh ikatan pertalian darah dan kekerabatan, sehingga sekalipun mereka melakukan pelanggaran atau kesalahan di luar kampung Bonsor, namun orang-orang Bonsor akan tetap mendapatkan sanksi adat yang berlaku dalam kehidupan mereka. Setiap orang Bonsor akan terikat secara rohani dengan adat-istiadat mereka, sehingga mempengaruhi seluruh hidup dan tata kelakukan mereka dimanapun mereka berada.

Sebagaimana hukum adat yang ada di Indonesia berlaku pada masing-masing suku dengan kebudayaan tertentu, eksistensi adat di Binua Sakanis Dae, hanya berlaku pada wilayah adat Sakanis Dae dan masyarakat binua tersebut. Namun, ada kalanya hukum adat pada kasus tertentu dapat berlaku di luar wilayahnya. Pengecualian terhadap sanksi adat biasanya berlaku, jika seseorang yang tidak tinggal di wilayah tersebut (hukum adat) melakukan pelanggaran adat, misalkan menyebarkan fitnah atau penghinaan. Di samping itu, terdapat kekurangan pada penanganan kasus hukum, yakni tidak memiliki otoritas pengadilan yang lebih tinggi atau kredibel serta jangkauanya terbatas secara geonologis dan teritorial. Pendekatan pengadilan umumnya mengharuskan para pihak untuk membuktikan hukum adat sebagai pembuktian fakta dan untuk menghasilkan bukti yang otentik sesuai dengan adat yang berlaku. Sebagian besar masyarakat adat menjunjung tinggi hukum adat, bahkan beberapa orang merasakan bahwa hukum adat lebih dihormati dari pada hukum negara. Keyakinan tentang hukum adat oleh sebagian besar masyarakat sudah menjadi sebuah credo yang sakral bahkan diyakini memliki nilai keadilan yang lebih baik daripada hukum negara pada umumnya.

Antropologi memandang hukum sebagai aspek yang terintegrasi dan integral dari kebudayaan dan keseluruhan hidup manusia pemiliknya. ${ }^{55}$ Mengacu pada hukum dalam perspektif antropologi, eksistensi adat sebagai gejala hukum dipelajari sebagai produk dari kehidupan sosial budaya masyarakat di Kampung Bonsor. Fenomena diakuinya adat sebagai sistem nilai dan hukum oleh masyarakat di Kampung Bonsor menunjukkan bahwa hukum dalam masyarakat yang sederhana, tidak melulu tampak dalam wujud perundang-undangan, namun lebih tampil sebagai seperangkat norma yang bersumber dari kebiasan turun temurun yang mengikat seluruh anggotanya. Adat sebagai pengendali keteraturan sosial (social order) pada Masyarakat Dayak di kampung Bonsor mengikat seluruh masyarakat kampung yang jangkaunnya bersifat Teritorial Genealogis. Secara genealogi masyarakat Dayak menganut sistem parental dan bilateral, sehingga

55 Yusnita Eva, 'Perspektif dan Kajian Hukum dari Beberapa Tokoh dalam Bidang Antropologi Hukum' (2010) 22 (1) Mimbar Hukum 170. 
jangkauan adat mengikat seluruh masyarakat dan bersifat luas, namun dibatas pada teritori wilayah adat pada Binua Sakanis Dae.

Perhatian antropologis terhadap berbagai bentuk hukum dalam masyarakat manusia terfokus pada berfungsi adat-istiadat sebagai cara masyarakat manusia memecahkan masalah yang ditimbulkan oleh kepentingan dan perselisihan yang berbeda. ${ }^{56}$ Pola kepemimpinan terstruktur yang bersifat tradisional, serta prosedur penyelesaian sengketa/permasalahan yang terstruktur, pada masyarakat Dayak di kampung Bonsor merupakan suatu tatanan atau mekanisme hukum dalam satu ruang sosial-budaya, berdasarkan organisasi berbentuk Binua, dengan orotitas tertinggi pada kepemimpinan seorang Timanggung. Prosedur penyelesaian perkara melalui adat ini dilakukan pula secara berjenjang berdasarkan besaran sanksi adat yang dikenakan kepada pelaku pelanggar adat juga menunjukan terdapatnya gejala hukum dalam kehidupan masyarakat secara tradisional yang dilakukan secara logis dan masuk akal, yang sebanding dengan fenomena hukum pada hukum negara. Fenomena ini, mempertegas kajian Gluckman, dalam studinya tentang pengambilan keputusan di pengadilan pribumi di Rhodesia utara, menemukan bahwa hakim Lozi mengambil keputusan melalui proses logis dan masuk akal. ${ }^{57}$

Keempat fenomena yang diuraikan sebelumnya, memperlihatkan bahwa adat merupakan nilai-nilai yang hidup dan berkembang di dalam masyarakat Kampung Bonsor, sekalipun hukum-hukum itu tidak tertulis, namun kekuatanya memiliki daya ikat yang kuat. Fenomena ini, memberikan gambaran bahwa masyarakat di Dusun Bonsor merupakan etnis Dayak, suatu kesatuan asli atau indigenous people $e^{58}$ yang masih melaksanakan tradisi leluhur meskipun norma dan nilai-nilai itu tidak dalam bentuk tertulis. Maka dengan mengacu pada kodifikasi unsur-unsur hidup atau matinya masyarakat dan tradisi hukum adat dalam teori dan praktik ${ }^{59}$ maka: masyarakatnya masih asli $(\mathrm{M}+)$, tradisinya masih ada $(\mathrm{T}+)$, tetapi catatan tidak tersedia (C-). Kodefikasi yang diperoleh ialah $(\mathrm{M}+)+(\mathrm{T}+)+(\mathrm{C}-)$, dengan demikian adat dan masyarakat kampung Bonsor dikategori dalam masyarakat hukum adat yang memang dapat dikategorikan masih hidup dalam kenyataan. Dengan demikian, adat sebagai peradilan dalam keteraturan sosial masyarakat Bonsor, memiliki nilai-nilai yang bersumber dari nilai yang luhur yang dihidupi dan akan terus hidup dalam masyarakat sehingga ini menjadi fenomena the living law. Nilainilai dari adat yang luhur sangat diperlukan dalam menjawab kompleksitas pusaran arus globalisasi.

\section{PENUTUP}

Adat memiliki fungsi yang sentral dalam mengontrol keteraturan sosial Kampung Bonsor Binua Sakanis Dae. Setiap tindakan dan tata kelakuan hidup dijalankan berdasarkan adat dan diukur dengan norma adat. Adat memiliki fungsi

Marie Claire Foblets dan Maria Sapignoli. Law and Anthropology (The International Encyclopedia of Anthropology 2018) 1.

57 Max Gluckman, The Judicial Process among the Barotse of Northern Rhodesia (Manchester University Press 1995) 224.

58 Retno Winarni, 'Asimilasi Perkawinan Etnis Cina dengan Pribumi Di Jawa: Fokus Studi Di Jember Situbondo dan Tulungagung' (2017) 18 (1) Patrawidya: Seri Penerbitan Penelitian Sejarah dan Budaya 13. 
sebagai media untuk menjaga keteraturan sosial, bahkan keharmonisan semesta. Adat sebagai sistem hukum, merupakan representasi dari kehidupan masyarakat Bonsor Binua Sakanis Dae yang menjunjung tinggi nilai-nilai dan norma sosial yang baik, dipakai masyarakat untuk menjustifikasi tingkah dan pola kehidupannya. Masyarakat Bonsor Binua Sakanis Dae memiliki alasan-alasan yang khusus untuk menggunakan adat dalam menyelesaikan sengketa dan permasalahan sosial, yakni karena sifatnya yang konkret, tidak rumit, dapat dipahami bahkan tidak dikodifikasi dengan administrasi yang rumit. Sifatnya yang mengutamakan kepentingan bersama dari pada kepentingan pribadi, mengutamakan damai dan keharmonisan, membuat adat terus hidup dan menjiwai etnis lokal di Kampung Bonsor Binua Sakanis Dae

Eksistensi adat dalam kehidupan sosial dan budaya etnis Dayak di Kampung Bonsor, merupakan bagian dari pelestarian nilai-nilai luhur bangsa Indonesia. Sistem adat yang berlaku pada masyarakat adat merupakan bentuk asli dari kehidupan suku bangsa Indonesia yang heterogen. Eksistensi ini tentu menunjukkan adanya nilai-nilai yang luhur, yang dijiwai dan menghidupi masyarakat tersebut. Peradilan adat dengan nilai musyawarah, kekeluargaan, kedamaian dan keharmonisan sangat dijunjung tinggi oleh etnis Dayak di Kampung Bonsor. Meskipun peradilan adat ini berlangsung secara alamiah, sebagaimana yang dilakukan oleh leluhur mereka secara turun-temurun, adat ini telah menjadi pilihan utama dalam penyelesaian perkara sosial dan budaya bagi mereka. Peradilan adat di Bonsor lebih dihormati daripada peradilan negara, hal ini yang membuat keteraturan dan keharmonisan hidup di Kampung Bonsor.

Keberagaman sosial-budaya yang berkembang dalam kehidupan masyarakat Indonesia menjadi dasar dari keberagaman kehidupan sosial-politik, yang mengandung nilai dan norma sebagai dasar dalam keteraturan, serta pengendalian sosial yang menjadi the living law. The living law, suatu sistem hukum yang secara nyata mengatur kehidupan sehari-hari masyarakat, yang dalam keseharian masyarakat Indonesia dinyatakan dengan eksistensi hukum adat pada tiap-tiap etnis. Oleh karena itu, perlindungan terhadap nilai adat sejauh tidak bertentangan dengan nilai-nilai pada hukum Negara, sangat pantas untuk diberi perlindungan. Perlindungan dapat dilakukan melalui penetapan hukum adat Binua Sakanis Dae sebagai warisan budaya tak benda, sebagaimana yang telah dilakukan pada hukum adat Dayak masyarakat Tanah Pinoh.60

\section{DAFTAR REFERENSI}

\section{Buku}

Agustinus E dan Mekarryani H, Penerapan Kearifan Lokal Adat Balala dalam 'pencegahan Penyebaran Pandemi Covid-19 di Kabupaten Landak' (Kristianus Atok dan Efriani ed. Derwati Press 2021).

60 Pada tahun 2011, Hukum adat Dayak masyarakat Tanah Pinoh telah ditetapkan sebagai warisan Budaya tak Benda dengan nomor Registrasi 2011001341, pada Domain Pengetahuan dan Kebiasaan Perilaku Mengenai Alam dan semesta.

Warisan Budaya Takbenda Indonesia, 'Hukum Adat Gabungan Tanah Pinoh' (warisanbudaya kemdikbud, 01 Januari 2011) < http://warisanbudaya.kemdikbud.go.id/?newdetail\& detailCatat $=1341>$ diakses pada 28 November 2021 . 
Asshiddiqqie J, Hukum Acara Pengujian Undang-Undang (Konstitusi Press 2006).

Creswell JW, Research Design: Qualitative, Quantitative, and Mixed Methods Approaches (ed. 3, SAGE Publications Inc. 2009).

Gluckman M, The Judicial Process among the Barotse of Northern Rhodesia (Manchester University Press 1995).

Hadikusumah H, Pegantar Antropologi Hukum (ed. 2, PT. Citra Aditya Bakti 2004).

Koentjaraningrat, Metode Antropologi dalm Penyelidikan Masyarakat di Indonesia (sebuah iktisar) (Universitas Indonesia 1958).

Koentjaraningrat, Sejarah Teori Antropologi I (Universitas Indonesia 1987)177-178.

Redfield R, The Primitive World and Its Transformation (ed. 11, Cornell University Press 1969).

Rufinus A, dkk, Tradisi Lisan Dayak Yang Tergusur dan Terlupakan (S. Djuweng, N. Andasputra, J. Bamba, \& E. Petembang ed., Institute Dayakologi 2003).

Saragih D, Hukum Adat Indonesia (Tarsito 1996).

Soekanto S, Meninjau Hukum Adat Indonesia: Suatu Pengantar untuk Mempelajari Hukum Adat (Rajawali 1996).

Sudiyat I, Asas-Asas Hukum Adat (Liberty Yogyakarta 1981).

\section{Jurnal}

Ahmad MY, 'Sanksi Adat sebagai Hukum Alternatif terhadap Bandar Narkoba di Kecamatan Lhoksukon, Aceh Utara' (2017)19 (2) Substantia.

Beckmann KVB, 'Anachronism, Agency, and the Contextualisation of Adat: Van Vollenhoven's Analyses in Light of Struggles Over Resources' (2019) 20 (5) Asia Pacific Journal of Anthropology.

Cooter RD dan Fikentscher W, 'Indian Common Law: The Role of Custom in American Indian Tribal Courts (Part II of II)' (1998) 46 (3) American Journal of Comparative Law.

Efriani dan Agustinus E, 'Reflection Of The Concept Of Sations And Law On The Tamambaloh Dayak Custom' (2021) 23 (2) Kanun Jurnal Ilmu Hukum.

Efriani, Budhi Gunawan dan K Garna Judistira, 'Kosmologi dan Konservasi Alam pada Komunitas Dayak Tamambaloh di Kalimantan Barat' (2019) 2 (2) Studi Desain.

Eva Y, 'Perspektif dan Kajian Hukum dari Beberapa Tokoh dalam Bidang Antropologi Hukum' (2010) 22 (1) Mimbar Hukum.

Foblets MC dan Sapignoli M, Law and Anthropology (The International Encyclopedia of Anthropology 2018) 1.

Herlambang, 'Membangun Asas-asas Peradilan Adat (Studi pada Masyarakat Rejang dan Masyarakat Melayu Bengkulu)' (2012) 14 (1) Kanun Jurnal Ilmu Hukum.

Herlan, dkk, 'Konsep sehat dan sakit pada Budaya Etnis Dayak Kebahan' (2020) 9 (1) Etnoreflika: Jurnal Sosial dan Budaya. 
Irianto S, 'Sejarah dan perkembangan pemikiran pluralisme hukum dan konsekuensi metodologisnya' (2003) 33 (4) Hukum dan Pembanguan.

Kaliki I, 'Perkawinan dan Sanksi Adat pada Masyarakat Negeri Luhu' (2016) 12 (2) Tahkim.

Kurniawan JA, 'Pluralisme Hukum dan Urgensi Kajian Socio-Legal Menuju Studi dan Pengembangan Hukum yang Berkeadilan Sosial' (2012) 27 (1) Yuridika.

Kurniawan, 'Eksistensi masyarakat Hukum Adat dalam Lembaga-lembaga Adat di Aceh dalam Penyelenggaraan Keistimewaan dan Otonomi Khusus di Aceh' (2012) 1 (3) Yustisia.

Kusumaryati V, 'Adat Institutionalisation, the State and the Quest for SelfDetermination in West Papua' (2019) 21 (1) Asia Pacific Journal of Anthropology.

Maladi Y, 'Eksistensi Hukum Adat dalam Konstitusi Negara Pasca Amandemen' (2010) 22 (3) Mimbar Hukum.

Martono, dkk, "The National Identity On The Border: Indonesian Language Awareness And Attitudes Through Multi Ethnic Community Involvement' [2021] Journal Community Psychology.

Masyithoh ND, 'Dialektika Pluralisme Hukum: Upaya Penyelesaian Masalah Ancaman Keberagaman dan Keberagamaan di Indonesia' (2016) 24 (2) Walisongo: Jurnal Penelitian Sosial Keagamaan.

Primawardani Y, 'Perlindungan Hak Masyarakat Adat dalam Melakukan Aktivitas Ekonomi, Sosial dan Budaya Di Provinsi Maluku' (2017) 8 (1) Jurnal HAM.

Safrijal A, 'Penerapan Sanksi Adat dalam Penyelesaian Perkara Pidana di Kabupaten Nagan Raya' (2013) 15 (1) Kanun Jurnal Ilmu Hukum.

Saleh M, 'Eksistensi Hukum Adat dalam Polemik Hukum Positif suatu Kajian Dalam Perpektif Tata Negara' (2013) 1 (3) Kajian Hukum dan Keadilan.

Sambas N, 'Eksistensi Hukum Pidana Adat dalam Pembentukan Hukum Pidana Nasional' (2009) 11 (3) Syiar Hukum: Jurnal Ilmu Hukum.

Simanjuntak E, 'Peran Yurisprudensi dalam Sistem Hukum di Indonesia' (2019) 16 (1) Jurnal Konstitus.

Sudaryanto A dan Riyanto S, 'Eksistensi delik adat di lingkungan masyarakat Sentolo, Kabupaten Kulonprogo Yogyakarta' (2016) 28 (1) Mimbar Hukum.

Sulaiman, 'Mereposisi Cara pandang Hukum Negara terhadap Hukum adat di Indonesia' (2017) 2 (1) Petita.

Supusesa R, 'Eksistensi Hukum Delik Adat dalam Perspektif Pembaharuan Hukum Pidana di Maluku Tengah' (2012) 24 (1) Mimbar Hukum.

Svensson TG, 'On Customary Law: Inquiry into an Indigenous Rights Issue' (2003) 20 (2) Acta Borealia.

Thontowi J, 'Perlindungan Dan Pengakuan Masyarakat Adat dan Tantangannya dalam Hukum Indonesia' (2013) 1 (20) Jurnal Hukum Ius Quia Iustum.

Usman NARL, 'Eksistensi Masyarakat Hukum Adat dalam Penguatan Desa Adat di Desa Bentenan Kabupaten Minahasa Tenggara' (2015) 3 (7) Lex et Societatis. 
Winarni R, 'Asimilasi Perkawinan Etnis Cina dengan Pribumi Di Jawa: Fokus Studi Di Jember Situbondo dan Tulungagung' (2017) 18 (1) Patrawidya:Seri Penerbitan Penelitian Sejarah dan Budaya.

Wiratraman HP, 'Perkembangan Politik Hukum Peradilan Adat' (2018) 30 (3) Mimbar Hukum.

\section{Seminar}

Efriani, 'Adat Suku Dayak Tamambaloh Sebagai Pengendali Sosial, Bukanlah Hukum Adat (Pengamatan Ontologis, Epistemologis dan Aksiologis)' (Simposium Kebudayaan Indonesia-Malaysia, Bandung 13 November 2013.

\section{Website}

Warisan Budaya Takbenda Indonesia, 'Hukum Adat Gabungan Tanah Pinoh' (warisanbudaya kemdikbud, 01 Januari 2011) < http://warisanbudaya. kemdikbud.go.id/?newdetail\&detailCatat $=1341>$ diakses pada 28 November 2021. 